\title{
Competitiveness of Government Organizations through Customer Satisfaction in a Knowledge Economy: Study in the Kingdom of Bahrain
}

\author{
Haitham Jahrami Ph.D. (Corresponding author) \\ Ministry of Health \\ P.O. Box 5128, Manama, Bahrain \\ Tel: +973 17286334 Fax: +973 17270637 E-mail: hjahrami@health.gov.bh
}

Mohammed Jassim Buheji Ph.D.

Bahrain Centre of Excellence, Court of Prime Minister, Bahrain

Tel: +973 17212220 Fax +973 17213322 E-mail: buhejim@gmail.com

Accepted: November 02, 2013

doi:10.5296/ jpag.v3i4.4931 URL: http://dx.doi.org/10.5296/ jpag.v3i4.4931

\begin{abstract}
The field of customer satisfaction continues to be an important element of any governmental development programs. While most studies are based on the customer satisfaction of a product or service, there are relatively few studies associated with the satisfaction level of "competitiveness" of governmental organisations through customer satisfaction especially in today's growing knowledge economy. This national customer satisfaction has become a major issue for Bahrain to enhance its competitiveness worldwide. The study used researchers-developed questionnaire in a cross-sectional research methodology to collect data for this research from 32 governmental entities in the Kingdom of Bahrain in 2012. Totally, 9535 questionnaire we entered the analysis to estimate the level of customer satisfaction about the competitiveness of governmental organisation in Bahrain. Customer satisfaction with governmental organisation competitiveness was generally good. The highest areas were organisation's ability to identify new services opportunities and ability to meet the customers' demands. The lowest areas were organizations' has mechanisms to deal with customer complains, consumers feedback and sustainability of services. The main contribution of this research is that how governments may, through national customer satisfaction survey, add value towards their competitiveness.
\end{abstract}

Keywords: Organizational Competitiveness, Customer Satisfaction, Knowledge Management, Bahrain 


\section{Introduction}

In the increasingly competitive environment, governments must be customer oriented in order to demonstrate competitiveness in the services provided to the public. Modern public administration considers customer satisfaction as a baseline standard of performance and a major standard of excellence for any governmental organization. To reinforce customer orientation on a regular basis, growing number of governmental organizations choose customer satisfaction as key performance indicator in their measurement dashboards or balanced scorecards. The focus of this research project is not on traditional approaches to customer satisfaction, but rather it focuses on the customers' level of satisfaction with the 'competitiveness' of organizations. Traditionally, customer satisfaction is the degree to which a customer perceives that an individual, department or organization has effectively provided a product or service that meets the customer's needs in the context in which the customer is aware of and or using the product or service.

Customer satisfaction in relation to organizational competitiveness was acquired by measuring government organizations' ability to identify new services opportunities, ability to adapt quickly to unanticipated changes, ability to create a good profitable income for government organization and ability to react to customer demands. The competitiveness of the organization was also measured by its ability to streamline the processes, ability to ensure sustainability of services, ability to form analytical capabilities that lead to learning from mistakes and ability to adopt unique way in dealing with customers in intimacy. The study used measures as the ability to establish unique values with its employees that are difficult to copy and ability to have established high quality services or products with low cost and high speed of delivery.

Competitiveness is no longer rooted in physical assets and financial capital, but in effective channeling of successful growth and longevity in business where human capital pushes organizations towards higher capacity to learn (Phusavat et al., 2010; Halawi, 2005). To be competitive means that organizations must have unique and sustainable set of values that deliver both tangible and intangible assets that reflect onto management skills, organizational processes and routines that in turn become valuable, rare and very difficult to imitate (Barney, 1991). This resource-based view of competitiveness has been re-emphasized later by Drucker (2002) whom realized that competitive organizations must have the ability to shift from tangible to value based measures meaning that organizational performance capabilities would be based more on the organizational internal resources. Yeh et al. (2006) believe that a key component in organizational competitiveness is the organization ability to realize the full potential of its intellectual assets in strategic and tactical decision making. Thus organizational competitiveness is thought to occur due to accumulation of values that comes from organizational internal developments when utilized and sustained, brings in practices as knowledge creation and sharing which bring in learning and innovation activities that are based on internal resources (Lin, 2007; Halawi et al., 2005). 


\section{Macrothink}

\section{Method}

\section{Design and Study Participants}

The study used the cross-sectional research methodology to collect data for this research. The research was conducted in September, 2012 using a sample from all of the governmental organizations that provide direct or indirect services to the public and are enrolled in the Bahrain Centre of Excellence's Competitiveness Lab. Together, 32 governmental organizations (ministries, authorities and public institutes participated) in the survey.

\section{Data Collection Instrument}

The organizational competitiveness elements in the KM-OC Questionnaire were used in this research study. The KM-OC questionnaire was developed and validated by one of the researchers as part of his doctoral degree. The KM-OC questionnaire is scientifically sound with high psychometric properties.

\section{Procedures}

The researchers created a draft of this research tool; the customer satisfaction of governmental organizations' competitiveness; using the KM-OC questionnaire items from the section related to organizational competitiveness. In June, 2012 half-day workshop was called to revise the research tool, agreed on coding approach, selected targeted sample for administration and standardized procedure for data collection. Totally, 78 consultants attended workshop held in the Court of Prime Minister, Bahrain, the results of the workshop were: final research tool, electronic sheet for data entry, a uniform approach to select the sample within each institution. Two members were assigned from each organization to act as research coordinators and liaised their activities with the principal investigator.

In July, 2012 the research coordinators started dispatching the questionnaires to the organization's customers, two weeks were allowed before closing the survey. The responses were coded and entered to the electronic data-entry sheet and was forwarded to the principal investigator. Random surveys from each organization were collected and verified as a data integrity measure by the researchers.

\section{Data Analysis}

Responses from all of the organizations were exported into the Statistical Package for Social Sciences (PASW/SPSS 18). The analysis includes descriptive statistics including minimum, maximum, mean, and standard deviation.

Psychometric properties of the tool were also examined as new customer satisfaction index tool. The coefficient of reliability or internal consistency was computed using the standard procedure of Cronbach alpha of the sum of items making a domain. Discriminant validity was judged via an approach akin to Gaski approach in measuring convergent and discriminant validity whereby within each domain each item was correlated with every other item. 


\section{Macrothink}

\section{Results}

Altogether, 9535 questionnaires were provided by 32 governmental organizations to estimate the level of customer satisfaction about the competitiveness of governmental organizations in the Kingdom of Bahrain. Each organization contributed to this research with approximately 300 questionnaires.

Procedure Cronbach alpha were used to estimate the internal consistency of the items in measuring organizational competitiveness, results of the procedure indicated high consistency with an alpha coefficient of 0.93 .

The twelve items correlates positively and highly significant indicating construct validity. Table 1 shows the inter-correlations between the items.

\begin{tabular}{|c|c|c|c|c|c|c|c|c|c|c|c|c|}
\hline \multicolumn{10}{|c|}{ Table 1 Correlations between the Items } \\
\hline Items & 1 & 2 & 3 & 4 & 5 & 6 & 7 & 8 & 9 & 10 & 11 & 12 \\
\hline 1 & 1.00 &. & & & & & & & & & & \\
\hline 2 & 0.659 & 1.00 & & & & & & & & & & \\
\hline 3 & 0.537 & 0.499 & 1.00 & & & & & & & & & \\
\hline 4 & 0.548 & 0.521 & 0.481 & 1.00 & & & & & & & & \\
\hline 5 & 0.580 & 0.568 & 0.510 & 0.604 & 1.00 & & & & & & & \\
\hline 6 & 0.522 & 0.527 & 0.462 & 0.447 & 0.530 & 1.00 & & & & & & \\
\hline 7 & 0.507 & 0.508 & 0.437 & 0.540 & 0.559 & 0.521 & 1.00 & & & & & \\
\hline 8 & 0.513 & 0.490 & 0.464 & 0.556 & 0.532 & 0.518 & 0.568 & 1.00 & & & & \\
\hline 9 & 0.518 & 0.539 & 0.434 & 0.515 & 0.565 & 0.514 & 0.543 & 0.525 & 1.00 & & & \\
\hline 10 & 0.598 & 0.558 & 0.515 & 0.568 & 0.599 & 0.541 & 0.554 & 0.572 & 0.606 & 1.00 & & \\
\hline 11 & 0.553 & 0.582 & 0.485 & 0.531 & 0.574 & 0.574 & 0.598 & 0.559 & 0.547 & 0.627 & 1.00 & \\
\hline 12 & 0.538 & 0.533 & 0.475 & 0.513 & 0.557 & 0.569 & 0.583 & 0.548 & 0.521 & 0.590 & 0.696 & 1.00 \\
\hline
\end{tabular}

*. Correlation is significant at the 0.01 level (2-tailed).

Results in Table 2 indicates that the average level of satisfaction is fair with a mean score of 3.54 (SD 0.92) for the entire sample. The highest areas of competitiveness satisfaction were (a) Organization has improved its ability to identify new services opportunities and (b) Organization has the ability to react to customer demands. The lowest areas of competitiveness satisfaction were (a) Organization has mechanisms to deal with customer complains (b) Organization has plans for future that would ensure sustainability of services (c) Organization considers consumer feedback seriously. 
Table 2 Mean Scores of Satisfaction By Dimension

\begin{tabular}{|l|c|c|c|c|}
\hline \multicolumn{5}{|c|}{ Table 2 Mean Scores of Satisfaction By Dimension } \\
\hline \multicolumn{1}{|c|}{ Item } & M*GOs & $\begin{array}{c}\text { SD** } \\
\text { GOs }\end{array}$ & $\begin{array}{c}\text { Minimum } \\
\text { GO }\end{array}$ & $\begin{array}{c}\text { Maximum } \\
\text { GO }\end{array}$ \\
\hline $\begin{array}{l}\text { 1. Organization has improved its ability to } \\
\text { identify new services opportunities }\end{array}$ & 3.81 & 1.10 & 2.84 & 4.67 \\
\hline $\begin{array}{l}\text { 2. Organization adopts quickly to unanticipated } \\
\text { change }\end{array}$ & 3.57 & 1.20 & 2.65 & 4.44 \\
\hline $\begin{array}{l}\text { 3. Organization can create a good profitable } \\
\text { income for government with Return on } \\
\text { Investment }\end{array}$ & 3.66 & 1.19 & 2.62 & 4.75 \\
\hline $\begin{array}{l}\text { 4. Organization has the ability to react to } \\
\text { customer demands }\end{array}$ & 3.77 & 1.16 & 2.93 & 4.78 \\
\hline 5. Organization always streamline it processes & 3.61 & 1.16 & 2.74 & 4.83 \\
\hline $\begin{array}{l}\text { 6. Organization has plans for future that would } \\
\text { ensure sustainability of services }\end{array}$ & 3.33 & 1.28 & 2.30 & 4.57 \\
\hline $\begin{array}{l}\text { 7. Organization has mechanisms to deal with } \\
\text { customer complains }\end{array}$ & 3.31 & 1.26 & 2.46 & 4.75 \\
\hline $\begin{array}{l}\text { 8. Organization has a unique value-guided way } \\
\text { in dealing with customers }\end{array}$ & 3.65 & 1.17 & 2.73 & 4.71 \\
\hline $\begin{array}{l}\text { 9. Organization has high speed of service / } \\
\text { product delivery }\end{array}$ & 3.48 & 1.36 & 2.61 & 4.67 \\
\hline $\begin{array}{l}\text { 10. Organization has established high quality } \\
\text { services / products }\end{array}$ & 3.67 & 1.14 & 2.75 & 4.42 \\
\hline $\begin{array}{l}\text { 11. Organization has analytical capabilities that } \\
\text { leads to learning from mistakes }\end{array}$ & 3.38 & 1.24 & 2.51 & 4.38 \\
\hline $\begin{array}{l}\text { 12. Organization considers consumer feedback } \\
\text { Seriously }\end{array}$ & 3.35 & 1.28 & 2.45 & $\mathbf{0 . 9 2}$ \\
\hline
\end{tabular}

*Mean Scores

** Standard Deviation

\section{Discussion}

The findings show that Government of Bahrain represented by its organizations has improved its ability to identify new services opportunities, i.e. its ability to innovate; to the extent that now it has the ability to react to customer demands. This means that overall the Government of Bahrain through the implementation of different Competitiveness Labs as per the type of the services is becoming more agile to meeting the competitiveness demands of its customers.

However, this enhanced governmental agility is hampered by its organizations ability to establish mechanisms that would deal with customer complaints and feedback. Also, the government ability to have an autonomous sustainable competitiveness still need to be challenged as there are no clear future plans as per its customer's point of view. This means 
that the government need to review its plan of competitiveness and involve the citizen in being aware of these labs and also ensure that the execution of these plans reflects clearly on the level of the services provided. This means that the Centre of Excellence in Bahrain under a pressure now to shift from different isolated Competitiveness Labs in the ministries to a Holistic Integrated approach Competitiveness Labs where more ministries come into the picture as a clear plan and clear National Indicators. This achievement should enhance the participation of the citizen to enhance their belief in the plans executions and service improvements. Also, Government of Bahrain should be more serious about it Customer Satisfaction programs be it customer complaints or customer feedback and satisfaction schemes.

Discipline scholars see a strong link between the capability of creating and utilizing knowledge and what makes organizations competitive (Grant, 1996; Nonaka, 1998). Thus, $\mathrm{KM}$ is seen more and more as the management intention that would improve the wisdom of the organization which lead to better decision-making, increase innovation, better performance that eventually leads to sustainable competitive outcomes (Rhodes et al., 2008). KM enhances organizations ability to even produce new knowledge and help boost knowledge transfer which enhances the government organization competitiveness through sustained changing processes (Bogner and Bansal, 2007; Raadschelders, 2005). Empirical work by Zheng et al (2010) and Hsu (2008) have shown that the success in KM implementation and using knowledge sharing can have a high potential of enhancing organization competitiveness. Carneiro (2000) proposed that KM initiatives can be as a source for higher human value that would lead to higher level of organizational competencies. Following a different perspective; Zheng et al. (2010) argues that KM influence can come from infrastructure and not practices only. However, the latest work by Mills and Smith (2011) for example, shows that now more and more authors believe that the only source of KM influence related to organizational competitiveness comes from direct knowledge applications and practices. Prominent scholars Davenport and Prusak (2000), actually emphasis that KM practices need to fit the organizational context in order to create a competitive edge. Rhodes et al (2008) believes that such practices of KM can be examined through a more balanced approach of assessing organizational non-financial performance indicators that can be leveraged to develop key organizational capabilities which are difficult for competitors to imitate. However it is believed that unless this $\mathrm{KM}$ is kept and maintained at superiority through specific practices as in learning; organizations would find themselves at a competitive disadvantage in the future (Zack et al., 2009).

The competition of today requires more than just organization capabilities; it is about speed of reacting to need. In GO's, the issue of lean governments is pushing such organizations to be more effectiveness, cost and delivery time conscious compared to before. The faster GO's plan and implement an effective response, the more likely they will succeed over their competitors in delivering value to the customer. In addition, the more a response is based on knowledge of the business environment as opposed to internal politics, and the faster a response is planned and implemented, the more likely that greater value will be delivered relative to competitors' differentiation, (Fugate et al., 2009). However despite extensive 
review, the literature appears to have failed to address the type of competitive practices that could occur through KM. More work is recommended along the line of this study. Future research in the topic should investigate the importance of customer satisfaction index on multiple organizational prevalent variable these should include organizational leadership, organizational innovation, organizational learning and organizational values. Comparative studies between national cultures are also needed by future researchers to narrow the gap in our understanding about organizational competitiveness globally.

\section{Acknowledgement}

The authors would like to thank the participating organizations. Special thanks go to the co-ordinators of data collection within each organization, without their help and support this research was impossible.

\section{References}

Barney, J. (1991) Firm Resources and Sustained Competitive Advantage, Journal of Management, 17(1): 99-120.

Bogner, W. and Bansal, P. (2007) Knowledge Management as the Basis of Sustained High Performance. Journal of Management Studies, 44(1):168-188, Jan.

Buheji ,M. and Al-Zayer, J. (2010) Developing a KM Maturity Model for GO Organizations towards competitiveness, 7th International Conference on Intellectual Capital, Knowledge Management and Organizational Learning - ICICKM Conference. Hong Kong Polytechnic University, China 11-12 November.

Carneiro, A (2000) How does knowledge management influence innovation and competitiveness? Journal of Knowledge Management, 4(2): 87-98.

Davenport, T.H. and Prusak, L. (2000). Working Knowledge: How Organizations Manage What They Know, Boston: Harvard Business School Press.

Drucker, P. (2002) Managing in the Next Society, USA.

Fugate,B , Stank,T and Mentzer,J (2009) Linking improved knowledge management to operational and organizational performance, Journal of Operations Management, 27: 247-264.

Grant, R. (1996) Toward a knowledge-based theory of the firm, Strategic Management Journal, 17(3), Winter, pp. 109-122.

Halawi L, Aronson J and McCarthy R (2005) Resource-Based View of Knowledge Management for Competitive Advantage, The Electronic Journal of Knowledge Management, 3(2): 75-86, available online at www.ejkm.com.

Hsu, I. (2008) Knowledge sharing practices as a facilitating factor for improving organizational performance through human capital: A preliminary test. Expert Systems with Applications, 35:1316-1326. 
Lin, H. (2007) Knowledge sharing and firm innovation capability: an empirical study. International Journal of Manpower, 28(3/4):315-332.

Mills,A and Smith,T (2011) Knowledge management and organizational performance: a decomposed view, Journal of Knowledge Management. 15(1): 156-171.

Nonaka, I. (1998), The knowledge-creating company, Harvard Business Review on Knowledge Management, Harvard Business School Publishing, Boston, MA, pp. 21-45.

Phusavat, K., Anussornnitisarn, P. , Patthananurak, P., Kekale, T., Helo, P. (2010) Sustaining Organizational Development Through Knowledge Management in The Public Sector, International Journal Of Sustainable Economy, 2(1): 16-31.

Raadschelders,J (2005) Government and Public Administration: Challengers to an need for connection. Administrative Theory and Praxis, 27(4): 602-627.

Rhodes, J.; Hung, R ; Lok, P ; Ya-Hui Lien,B and Wu,C (2008) Factors influencing organisational knowledge transfer: implication for corporate performance, Journal of Knowledge Management, 12(3): 84-100.

Yeh, Y., Lai, S. and Ho, C. (2006) Knowledge management enablers: a case study, Industrial Management \& Data Systems, 106(6): 793-810.

Zheng, W. ; Yang, B. and McLean, G. (2010) Linking organizational culture, structure, strategy, and organizational effectiveness: Mediating role of knowledge management, Journal of Business Research, 63:763-771.

\section{Copyright Disclaimer}

Copyright reserved by the author(s).

This article is an open-access article distributed under the terms and conditions of the Creative Commons Attribution license (http://creativecommons.org/licenses/by/3.0/). 